\title{
Structural Changes in Serbian Industry during Transition
}

\author{
Article history \\ Received: 13 May 2013 \\ Sent for revision: 09 July 2013 \\ Received in revised form: 10 July \\ Accepted: 10 July 2013 \\ Available online: 11 July
}

\begin{abstract}
Transition is complex process whereby a country in transition is stimulating structural changes with the goal to achieve economic growth and improved social wellbeing. In this paper the authors strive to prove that during transition in Serbia, such changes in the structure of manufacturing industry occurred, that resulted with only modest growth which was, in fact, slower than in other transitional countries. By the means of theoretical and empirical approach the authors have come to conclusion that structural changes did not improve industry branches like the hi-tech industry that contribute the most to PPP generation. At the same time, some low productive industries have gained on importance, therefore holding the living standard on the low levels with no capacity to rapidly converge towards EU average, which was set as an ultimate goal of transition in Serbia.
\end{abstract}

Keywords: Industry structure, Transition, Restructuring

\section{Strukturne promene u industriji Srbije u periodu tranzicije}

Rezime: Tranzicija je kompleksan proces u kome se u određenoj zemlji podstiču strukturne promene sa ciljem da se ostvari ekonomski rast i povećanje blagostanja. Cilj istraživanja u ovom radu je da se pokaže da je tokom tranzicije u Srbiji došlo do takvih promena u strukturi, pre svega prerađivačke industrije, koje su rezultovale sa malim privrednim rastom, sporijim nego $u$ drugim zemljama u tranziciji. Primenom teorijskih i empirijskih metoda autori su došli do zaključka da se strukturne promene nisu ostvarile u granama kao što je tzv. "Hi-tech" industrija, koje najviše doprinose ubrzanom privrednom rastu. $U$ isto vreme, neke grane industrije koje su nisko-produktivne dobile su

\footnotetext{
${ }^{1}$ Economics Institute, ivan.nikolic@ecinst.org.rs

${ }^{2}$ Economics Institute, jovan.zubovic@ecinst.org.rs
} 
na značaju, povećavajući svoje učešće u privredi, što je uticalo da se standard zadrži na relativno niskom nivou. To je uticalo na smanjenje kapaciteta za konvergenciju ka Evropskom proseku kupovne moći, što je postavljeno kao osnovni cilj tranzicije u Srbiji.

Ključne reči: Struktura industrije, tranzicija, restrukturiranje

\section{Introduction}

Since 2000 transition in Serbia was mainly characterized by the implementation of the "first generation of reforms" - small scale privatization and restructuring of the economy, macroeconomic stabilization, price and foreign economic deregulation and liberalization, consolidation and privatization of the banking sector, as well as the beginning of EU accession process and the numerous regulatory adjustments. The main objectives of economic policy were the maintenance of macroeconomic stabilization, along with achieving high rates of economic growth.

Research conducted by some authors on changes in major economic indicators during the past decade (e.g. USAID, 2010; Bošnjak, 2011 etc.), showed that the relatively high average annual rate of economic growth in the period until 2008, was in the long run unsustainable. Such a growth was based on severe macroeconomic imbalances (internal and external), and unresolved structural problems.

Generally speaking, Serbia had made only modest advance in the development and implementation of one modern industrial policy. The government of Serbia had only at the beginning of 2011 adopted the Strategy and policy of industry development for the period between 2011 and 2020 (Government of Serbia, 2011). Thus, the first legislation that consistently and comprehensively determined the main development priorities of industry and the ways to achieve them has been adopted with one decade of delay. Privatization was from the beginning a euphemism for industrial policy. An even greater failure of economic power in Serbia was the illusion that privatization was the missing link for the release of the entrepreneurial potential, fresh inspiration and new enthusiasm, which would, ceteris paribus, recover the economy and eliminate the presence of structural weaknesses in the industry.

The aim of this paper is to show that in the period of transition in Serbia there have occurred significant changes in the structure of manufacturing industry and that despite the fact that Serbia could rely on experiences from other transition countries, those changes resulted with weaker progress as compared to those respective countries. 
In the first section of this paper we will go through some literature review related to structural changes and transition. Next section is devoted to comparison of macroeconomic data in transitional countries. Further on we will discuss on the patterns of industrial production in Serbia in the period of 19802012. Finally we will focus on the industry branches analysis and determine what effects the transition has brought to Serbian economy in the period of 12 transitional years. The paper closes with some concluding remarks.

\section{Methodology}

Structural change is a complex phenomenon which includes several stages in macroeconomic recomposition. Therefore it is necessary to give a brief literature review in order to set theoretical basis for the analysis of structural changes' effectiveness.

Changes should in theory bring economic growth through a process of adjusting such changes to different aspects of the economy. They include changes in the composition of output and employment, ownership of capital, business organization etc. In the quantitative section of the research we introduce measurable variables which will serve for comparison among different countries and in different time frames. They include purchasing power parity on the one side and transition indicators on the other side. Comparison with other transitional countries will provide information on development trends.

By the means of empirical analysis of the Serbian industry we disaggregate data into industry branches and observe their growth patterns. Changes in the structure of industrial production can be traced through weighted coefficients, which represent the approximate amount of value added share of each branch in total value added of the industry. Thus, the effect of unequal production coverage in certain branches was eliminated.

Data on gross value added are derived from the national accounts statistics and represent the value added ratio of a certain branch (two-digit classification of activities) to total gross value added of the industry (Equation 1).

$$
W i=\frac{G V A i}{\sum G V A i} * 100
$$

were:

$W_{i}$ represents weight for industry branch

$\mathrm{GVA}_{\mathrm{i}}$ represents gross value added of a certain branch 
Changes in dynamics of branches over the observed period and changes in the structure of manufacturing industry will serve as a tool for discovering the effectiveness of the conducted structural changes in Serbia.

\section{Literature review}

All former socialist countries in Europe including Serbia have in their transition towards a market economy gone under significant structural changes which still occur today. There is a lot of literature on the early effects of the structural changes in those countries (Berg 1994, Hansson 1995, Jackson 1997, Repkine and Jackson 1997). Current time series lasting over 20 years from the beginning of transition in 90's are long enough to conduct analysis in a more systematic and formal way.

The impact of structural changes on economic growth has been discussed during last few decades by several authors. The division of the economy in so called "three sector split", where the industry represents the medium stage has been improved by Chenery and Syrquin (1975), mostly with an aim of estimating the share of industry in the economy and changes among three sectors.

According to Landesmann (2000) structural changes are changes in compositional structures of output, employment, exports, etc. They may occur as a result of different types of shocks, such as plagues, wars, revolution, discovery of a continent and major technological breakthroughs. In this analysis, nevertheless, we look into the structural changes experienced by the economy during its development in the period of transition. This phenomena is very complex process, since it brings changes in various aspects of the economy. According to Zubović (2012) they include "changes in the sector composition of output and employment, the introduction of new industrial organization, the change of the role of the financial system, income and wealth distribution, demography, political institutions, and even value system in society". Moreover these changes in turn affect the processes of growth.

However, changes are not even within the economy. As Ngai et al (2007) have stated the economic growth takes place at uneven rates across different sectors of the economy with a goal of altering sectoral total factor productivity (TFP) growth rates. Structural change among other includes the state in which shares of at least some branches are changing over time. Therefore in the long term it is necessary to coordinate such changes with changes in strategic documents. 


\section{Results and Discussion}

\subsection{Comparison with other transitional countries}

The effects of the transition in Serbia are reflected in the per capita income, as measured by purchasing power parity (PPP) compared to other countries. Reaching EU average in terms of PPP is set as the ultimate goal of transition. As compared to some countries in transition with roughly similar economies Serbia had achieved the most convincingly weak qualitative shift. Therefore, the income of its residents is converging at the slowest pace towards EU average, which is presented in Fig. 1.

Figure 1 - Standard of living as measured by PPP in 2011 (EU27 = 100)

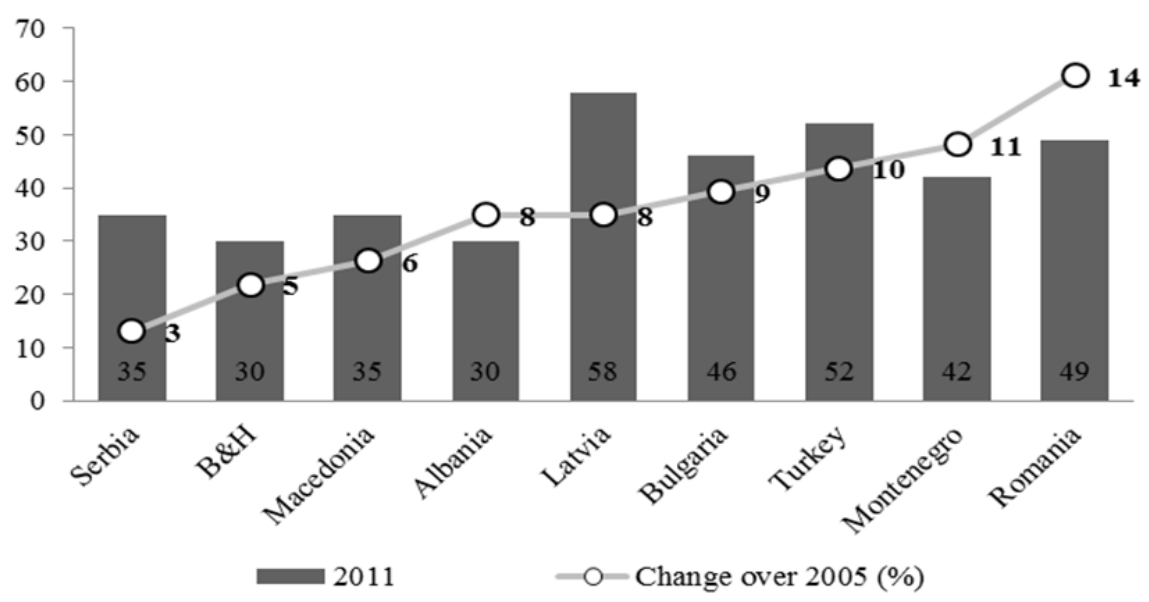

Source: Eurostat (2013); own calculations

Note: Coverage includes only countries with PPP 50\% or lower than EU27 average

Should we make a comparison on the advances in transition based on the parameters outlined by the EBRD (2012) Transition Report, Serbia would with no doubt receive a negative score. Serbia ended year 2012 placed at the bottom of comparable European countries, only one above the worst ranked Belarus. Contrasting by individual components (Table 1), we may note that Serbia failed in so called second phase of transition, which includes structural reforms and competitiveness policy. 
Nikolić I. et al.: Structural Changes in Serbian Industry during Transition

Table 1 - Values of transition indicators in some European countries in 2012

\begin{tabular}{lccccccc}
\hline & \multicolumn{3}{c}{ Companies } & \multicolumn{4}{c}{ Markets and Trade } \\
\hline & $\begin{array}{l}\text { large scale } \\
\text { privatisation }\end{array}$ & $\begin{array}{c}\text { small scale } \\
\text { privatisation }\end{array}$ & $\begin{array}{r}\text { restructu- } \\
\text { ring }\end{array}$ & $\begin{array}{c}\text { price liberali- } \\
\text { sation }\end{array}$ & $\begin{array}{c}\text { trade and } \\
\text { exchange } \\
\text { rate }\end{array}$ & $\begin{array}{c}\text { competiti- } \\
\text { veness } \\
\text { policy }\end{array}$ \\
\hline Alb & $4-$ & 4 & $2+$ & $4+$ & $4+$ & $2+$ \\
Blr & $2-$ & $2+$ & $2-$ & 3 & $2+$ & 2 \\
B\&H & 3 & 3 & 2 & 4 & 4 & $2+$ \\
Bul & 4 & 4 & $3-$ & $4+$ & $4+$ & 3 \\
Cro & $3+$ & $4+$ & $3+$ & 4 & $4+$ & 3 \\
Est & 4 & $4+$ & $4-$ & $4+$ & $4+$ & $4-$ \\
Mac & $3+$ & 4 & $3-$ & $4+$ & $4+$ & $3-$ \\
Hun & 4 & $4+$ & $4-$ & $4+$ & $4+$ & $4-$ \\
Let & $4-$ & $4+$ & $3+$ & $4+$ & $4+$ & $4-$ \\
Lat & 4 & $4+$ & 3 & $4+$ & $4+$ & $4-$ \\
Mol & 3 & 4 & 2 & 4 & $4+$ & $2+$ \\
MN & $3+$ & $4-$ & $2+$ & 4 & $4+$ & 2 \\
Pol & $4-$ & $4+$ & $4-$ & $4+$ & $4+$ & $4-$ \\
Rom & $4-$ & $4-$ & $3-$ & $4+$ & $4+$ & $3+$ \\
Rus & 3 & 4 & $2+$ & 4 & 4 & $3-$ \\
Ser & $3-$ & $4-$ & $2+$ & 4 & 4 & $2+$ \\
Svk & 4 & $4+$ & $4-$ & $4+$ & $4+$ & $4-$ \\
Slo & 3 & $4+$ & 3 & 4 & $4+$ & $3-$ \\
Ukr & 3 & 4 & $2+$ & 4 & 4 & $2+$ \\
\hline
\end{tabular}

Source: EBRD (2012).

Note: Indicators range from 1 for central planned economy up to 4+ for open market economies.

Therefore we may come to conclusion that compared to other transition countries Serbia is significantly trailing in most of the transitional indicators. Let us now focus on industrial production in Serbia.

\subsection{Trends in industrial production in Serbia}

Inherited structural problems from the past and sudden liberalization of the market, followed by a sharp real appreciation of the national currency, are among the reasons for the poor recovery of industrial production and its stagnant trend in the first decade of the new millennium.

The growth rates of the industry were characterized by extreme instability and high volatility. According to official statistics, the average yearly growth rate of industry in the period 2001-2012 stood at 0.4\% (Fig. 2) and it was well below the average growth rate of the whole economy of $3.4 \%$, while manufacturing industry recorded even worse. Given the fact that industrial growth was slower than the growth of total gross domestic product including primarily the service 
sector, deindustrialization process was becoming stronger over the observed period. This has created a number of imbalances and systemic distortions in the economy.

Figure 2 - Industrial production dynamics after 2000

(Physical volume index, 2000=100, trend-cycle)

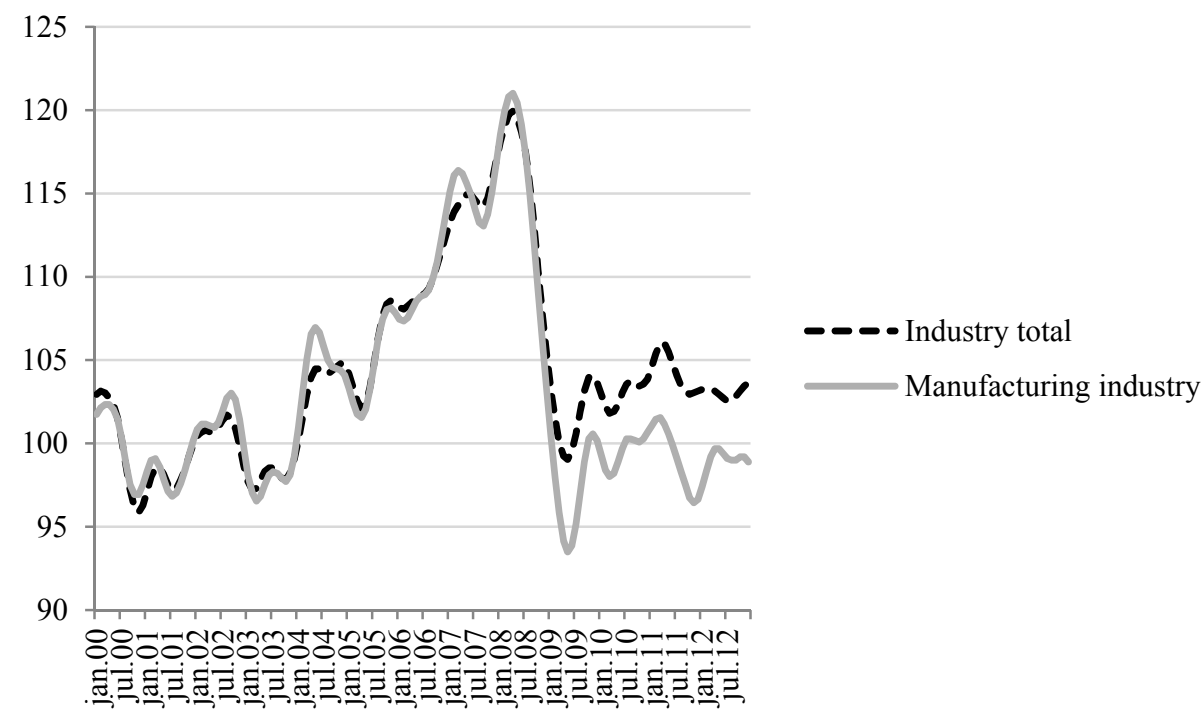

Source: Statistical office (2013), own calculations

A modest recovery of the manufacturing industry, of approximately only $17 \%$ until the 2008 financial crisis, and the further drop was probably one of the biggest disappointments of transition after 2000. A weaker result in Europe was reported in the observed period only by Macedonia. However, the real shock was yet to come. In the first six months of crisis in 2008/09, the production was drastically corrected downwards and returned to pre-transition level of 2000 .

Industrial structure is inadequate and is based on intensive subsectors, in terms of labour and resources. Results achieved so far in the processes of industrial restructuring, as well as the structure of the existing supply, can hardly, more dynamically, influence the growth of labor productivity, competitiveness and responsive performance in foreign markets. Insufficient competitiveness of Serbian industry causes the continuous deficit in foreign trade of goods, dominant share of the lower-level processing products in exports, dependence of overall export dynamics on the activities of several companies 
Nikolić I. et al.: Structural Changes in Serbian Industry during Transition

from the most important export-oriented sectors of the economy, etc. (Filipović et al, 2013).

\subsection{Subsector analysis}

In table 2 there are indices of the physical volumes of production presented by different industry branches, according to NACE rev. 2 classification. It is evident that compared to the starting year of transition there are only three manufacturing industry branches which nowadays that have significantly higher score. Moreover, observing the production trend over the longer period of time results in a finding that two out of named three branches which meet this criterion, have only slightly higher activity as compared to the period before 1999, while the tobacco industry production retuned to the level of three decades ago.

Table 2 - Industrial production in the selected branches of the Serbian manufacturing industry, 1980-2012 (physical volume indices)

\begin{tabular}{lrrrrr}
\hline & 1980 & 1989 & 1998 & 2007 & 2012 \\
\cline { 2 - 6 } & \multicolumn{5}{c}{$(2001=100)$} \\
& 193 & 267 & 121 & 115,0 & 103,4 \\
Industry sector & & & & & \\
& 118 & 129 & 107 & 127,1 & 117,7 \\
Food industry & 124 & 107 & 98 & 138,2 & 124,5 \\
Production of tobacco products & 195 & 216 & 107 & 42,6 & 23,5 \\
Production of textile yarns and fabrics & 128 & 151 & 125 & 152,5 & 107,5 \\
Production of coke and refined petr. products & 68 & 112 & 152 & 248,1 & 174,9 \\
Production of chemicals and chemical products & 42 & 50 & 107 & 127,0 & 120,8 \\
Production of rubber and plastics & 131 & 152 & 106 & 94,7 & 70,4 \\
Production of other non-metallic minerals & 112 & 125 & 173 & 229,4 & 105,0 \\
Production of base metals & 285 & 283 & 125 & 127,5 & 150,1 \\
Production metal products, except machinery & 683 & 871 & 130 & 132,8 & 146,9 \\
Production of el. machinery and equipment & 136 & 161 & 126 & 65,5 & 57,8 \\
Production of other machinery and equipment & 255 & 361 & 126 & 142,6 & 100,2 \\
Production of motor vehicles and trailers & 220 & 225 & 100 & 141,4 & 83,8 \\
\hline Production of furniture and related products & & & & & \\
\hline
\end{tabular}

Source: Statistical office (2013)

Textile industry has suffered the largest collapse. The decline therein was constant, so that this industry nowadays is reduced to one tenth of the 1980's 
levels. On the other hand, despite the production level which is about $46 \%$ higher than in 2001, due to strong contractions during the 90's, electric industry nowadays achieves the production which is, measured by physical volume, about 4.5 times lower than in 1980. The 2008 economic crisis invalidated a slight recovery in the production of furniture and motor vehicles ${ }^{3}$, which was present few years after the start of transition. The production level in these two branches was approximately 60\% lower than in 1980.

Figure 3 - Changes in weighted averages of electricity, gas and water production and supply branches (2002-2013)

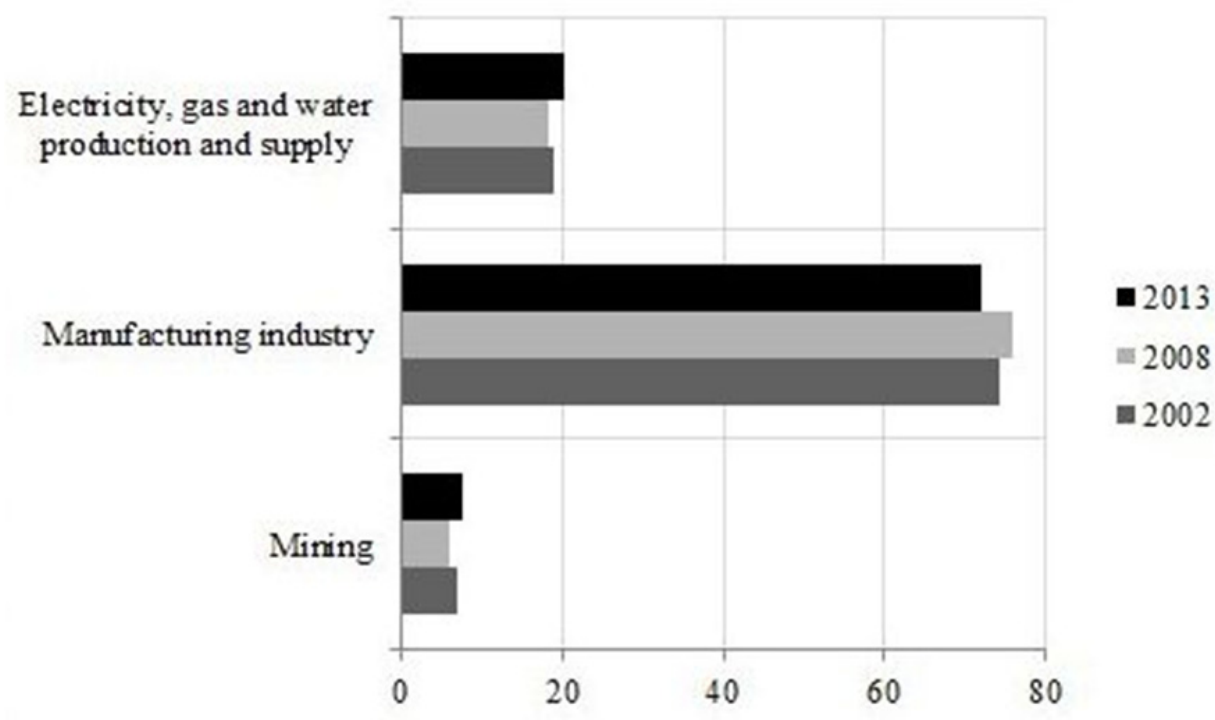

Source: Statistical office (2013)

We may observe that growth reported in certain branches is unexpectedly modest and insufficient. General changes in weight statistics is done every five years, but in the case of specific problems in the economy, this period may even be longer. Weight values in three years (2002 - the beginning of

\footnotetext{
${ }^{3}$ By launching of the new car production in "FIAT Automobili Srbija"(FAS), motor vehicles production recorded an extreme expansion in the second half of 2012. The production increased in this period by $70 \%$, and as much as 2.5 times in December 2012 compared to December 2011. The positive effect of such a structural change was first recorded in exports and improvement of foreign trade position of the country given, for example, that the very volume of physical activity in this field was $60 \%$ higher in 2005 when, due to large government subsidies, the Kragujevac factory produced the "Punto" model.
} 
privatization; 2008 - the year of conjuncture cycle fraction; 2013-current year) are provided in the Figure 3.

In addition, interpretation, for the sake of complete fairness, requires certain degree of caution. In fact, a change in the classification of activities during this period can lead to minimum differences in coverage of certain branches. We shall remind that, due to harmonization of national regulations with the EU standards, i.e. the standards of the European Statistical System, in July 2010 based on the Regulation and the Law on Classification of Activities, the Government of the Republic of Serbia replaced the previous classification by a new one (the so-called rev.2).

Despite the fact that industrial sector weights represent a change of gross value added, they obviously converge in the long run towards the movement of the production physical volume. The share of the manufacturing industry sector in total stock of Serbia's industrial production is now 2.2 points lower than in 2002. In the observed period, physical volume of total industrial production increase by $0.4 \%$ on average p.a. and of the manufacturing sector by only $0.1 \%$. Mining sector was mostly responsible for mild separation from stagnant industrial trend, since this industrial branch increased by $2.4 \%$ on average p.a. Also, electricity, gas and water production and supply reported an annual growth of $1.3 \%$.

Table 3 - Changes in the structure of manufacturing industry, 20022008 (change of total industry share, in percentage points)

\begin{tabular}{|c|c|c|c|}
\hline \multicolumn{2}{|c|}{ Branches with the fastest share growth } & \multicolumn{2}{|c|}{ Branches with the fastest share drop } \\
\hline Production of base metals & 3,15 & Other* & $-1,70$ \\
\hline $\begin{array}{l}\text { Production of chemicals and chemi- } \\
\text { cal products }\end{array}$ & 1,53 & $\begin{array}{l}\text { Production of clothing; finishing } \\
\text { and dyeing of fur }\end{array}$ & $-0,79$ \\
\hline $\begin{array}{l}\text { Production of food products and } \\
\text { beverages }\end{array}$ & 0,32 & $\begin{array}{l}\text { Production of textile yarns and } \\
\text { fabrics }\end{array}$ & $-0,50$ \\
\hline $\begin{array}{l}\text { Production of standard metal prod- } \\
\text { ucts, except machinery }\end{array}$ & 0,26 & $\begin{array}{l}\text { Production of non-metallic miner- } \\
\text { als }\end{array}$ & $-0,37$ \\
\hline $\begin{array}{l}\text { Production of furniture and various } \\
\text { products }\end{array}$ & 0,22 & $\begin{array}{l}\text { Tanning and finishing of leather, } \\
\text { manufacture of footwear }\end{array}$ & $-0,34$ \\
\hline $\begin{array}{l}\text { Production of rubber and plastic } \\
\text { masses }\end{array}$ & 0,12 & $\begin{array}{l}\text { Production of cellulose, paper } \\
\text { and paper products }\end{array}$ & $-0,27$ \\
\hline
\end{tabular}

Source: Statistical office (2013); Author's calculation

Note: *electronic, mechanical industry and other manufacturing activities

Thus, of all the branches with the highest increase in industrial production share in 2008, including production of base metals had transformed in the following five years into the biggest transition losers. 
On the other hand, production of non-metallic minerals, with cement industry as its recognizable representative entirely privatized during the first year upon enforcement of Privatization Law, reported weakening of its relative industrial position during 2008, and decline increased by as much as 1.2 percentage points ending with 2013.

Table 4 - Changes in the structure of manufacturing industry, 20022013 (change of total industry share, in percentage points)

\begin{tabular}{|c|c|c|c|}
\hline \multicolumn{2}{|c|}{ Branches with the fastest share growth } & \multicolumn{2}{|c|}{$\begin{array}{l}\text { Branches with the fastest share } \\
\text { drop }\end{array}$} \\
\hline $\begin{array}{l}\text { Production of standard metal prod- } \\
\text { ucts, except machinery }\end{array}$ & 3,70 & Production of base metals & $-2,02$ \\
\hline $\begin{array}{l}\text { Production of rubber and plastic } \\
\text { masses }\end{array}$ & 1,65 & $\begin{array}{l}\text { Production of textile yarns and } \\
\text { fabrics }\end{array}$ & $-1,47$ \\
\hline $\begin{array}{l}\text { Production of coke, refined petrole- } \\
\text { um products and nuclear fuel }\end{array}$ & 0,94 & $\begin{array}{l}\text { Production of non-metallic } \\
\text { minerals }\end{array}$ & $-1,34$ \\
\hline $\begin{array}{l}\text { Production of cellulose, paper and } \\
\text { paper products }\end{array}$ & 0,62 & $\begin{array}{l}\text { Production of chemicals and } \\
\text { chemical products }\end{array}$ & $-1,18$ \\
\hline $\begin{array}{l}\text { Wood processing and wood prod- } \\
\text { ucts except furniture }\end{array}$ & 0,62 & $\begin{array}{l}\text { Publishing, printing and repro- } \\
\text { duction }\end{array}$ & $-1,11$ \\
\hline $\begin{array}{l}\text { Production of motor vehicles, trailers } \\
\text { and semi-trailers }\end{array}$ & 0,43 & Other* & $-0,92$ \\
\hline
\end{tabular}

Source: Statistical office (2013); Author's calculation

Note: *electronic, mechanical industry and other manufacturing activities

Electronic and mechanical industries (presented in Tables under "Other") reported the worst results within manufacturing industry group until the crisisyear of 2008. Subsequently, the situation significantly improved upon arrival of the Slovenian "Gorenje" in Valjevo (greenfield investment). Textile industry was the representative of this branch, with long and steady decline (predominantly the production of textile yarn and fabrics, while the production of garments recorded a 0.5 p.p. decline in total industrial production share in the period 2002-2013). 


\section{Conclusions and recommendations}

Serbia has gone through a harsh economic structural change since the beginning of transition. Such change was not accompanied and followed by appropriate change in the development strategy.

There were no significant changes in industry branches that contribute the most to PPP generation like the hi-tech industry. In this period, as compared to other countries the share of the real sector stagnated, which has led to slower convergence towards the EU average.

Detailed analysis of weighted coefficients within the manufacturing industry has led us to a conclusion that its structure has significantly changed since 2000. On the other hand, branches that gave birth to former paragons of successful privatization are in a very difficult position.

In conclusion we may say that we have confirmed our hypothesis that structural changes in Serbia which occurred during transition have not resulted with sufficient growth that could provide sustainable improvement as compared to either other transitional countries or EU average.

\section{References}

Berg, A. (1994). Does Macroeconomic Reforms Cause Structural Adjustment?, Lessons from Poland. Journal of Comparative Economics, 18, 376-409.

Bošnjak, M. (2011). Rezultati i izazovi ekonomskih reformi u Srbiji u tranzicionom periodu 2001-2008. godine. (p. 56). Belgrade: Ministry of Finance.

Chenery, H.B., \& Syrquin, M. (1975). Patterns of Development, 1957-1970. London: Oxford University Press.

-EBRD. (2012). Transition Report 2012 - Integration across borders.

-Eurostat. (2013). Substantial cross-European differences in GDP per capita, Statistics in focus $-47 / 2012$.

Filipović, S., Miljković, M., \& Martinović, Đ. (2013). (Un)Competitiveness Of Serbian Industry - The Needs for Reindustrialization. Business Economics, 1, 35-59.

-Government of Republic of Serbia. (2011). Strategy and policy of industrial development of Serbia 2011-2020.

Hansson, A.H. (1995). Macroeconomic Stabilization in the Baltic States ", Stock-holm Institute of East European Economies. Stockholm: Stockholm Institute of East European Economies. working paper.

Jackson, M. (1997). Restructuring or Structural Change in Industry of Transition Countries: A Review of Issues. LICOS Centre for Transition Economics Katholieke Universiteit Leuven. Discussion Paper.

Landesmann, M. (2000). Structural Change in the Transition Economies, 1989 to 1999. Wien: WIIW. working paper.

Ngai, R.L., \& Pissarides, C. (2007). Structural change in a multi-sector model of growth. American economic review,97(1), 429-443. 
Repkine, A., \& Jackson, M. (1997). A Comparison of Structural Changes among the Branches of Industry in Seven Transition ountries. LICOS Centre for Transition Economics Katholieke Universiteit Leuven. Discussion Paper.

- Statistical Office of the Republic of Serbia. (2013). Online database. Retrieved from http://webrzs.stat.gov.rs/WebSite/public/ReportView.aspx

-USAID. (2010). Postkrizni model privrednog rasta i razvoja Srbije 2011-2020. (p. 370). Belgrade: Economics Institute, Faculty of Economics, USAID.

Zubović, J. (2012). Human capital development as a tool for managing structural changes - secondary education vs. structural changes. In J.S. Andrade, M.C.N. Simoes, \& et al. (Eds.), Managing Structural Changes : Trends and Requirements. (pp. 412-426). Coimbra: Faculty of Economics of the University of Coimbra. 